\title{
Return on political investment in the American Jobs Creation Act of 2004
}

\section{Citation}

Chen, Hui, Katherine Gunny, and Karthik Ramanna. "Return on Political Investment in the American Jobs Creation Act of 2004." Harvard Business School Working Paper, No. 15-050, December 2014.

\section{Permanent link}

http://nrs.harvard.edu/urn-3:HUL.InstRepos:13688358

\section{Terms of Use}

This article was downloaded from Harvard University's DASH repository, and is made available under the terms and conditions applicable to Open Access Policy Articles, as set forth at http:// nrs.harvard.edu/urn-3:HUL.InstRepos:dash.current.terms-of-use\#OAP

\section{Share Your Story}

The Harvard community has made this article openly available.

Please share how this access benefits you. Submit a story. 
H A R VAR D

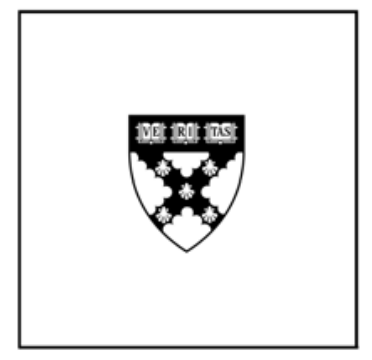

\section{Return on political investment in the American Jobs Creation Act of 2004}

Hui Chen

Katherine Gunny

Karthik Ramanna

\section{Working Paper}

15-050

December 3, 2014 


\title{
Return on political investment in the American Jobs Creation Act of 2004*
}

\author{
Hui Chen \\ University of Zürich \\ Katherine Gunny \\ University of Colorado at Boulder \\ Karthik Ramanna ${ }^{\dagger}$ \\ Harvard Business School
}

This draft: December 3, 2014

\begin{abstract}
Prior literature raises a "puzzle" of high rates of return on corporate political investment, but evidence for this puzzle is largely descriptive in nature. We exploit the setting of the American Jobs Creation Act's passage in 2004 to provide more robust estimates of political returns based on instrumentation in a two-stage regression model. We find for the median sample firm that an increase of $\$ 1$ million in lobbying spending is associated with about $\$ 32.35$ million in taxes saved. These estimates, while consistent with a high-returns "puzzle," are nearly an order of magnitude lower than those previously reported via descriptive methods.
\end{abstract}

Keywords: lobbying, multinationals, repatriations, returns, taxes

JEL classification: D72, F23, G18, H25, M41

\footnotetext{
"We thank Jennifer Blouin, Mihir Desai, C. Fritz Foley, David Gunther, Paul Healy, Jonas Heese, Linda Krull, Peter Merrill, Terry Shevlin, Eugene Soltes, Jerry Zimmerman, and workshop participants at Copenhagen Business School, Harvard University, and University of Oregon for helpful discussions; Brian Burnett, SangHyuk Byun, Greg Martin, Curtis Nicholls, and Qiuhong Zhao for research assistance; the Center for Responsive Politics for their data; and the University of Colorado at Boulder and Harvard Business School for financial support.

${ }^{\dagger}$ Corresponding author; Morgan Hall 389, Boston, MA, 02163; email: kramanna@hbs.edu; phone: 617-384-5739.
} 


\section{Introduction}

A large literature has examined the relation between firms and government in the United States, documenting the role of firms as contributors to politicians' campaigns and as lobbyists in the political process (for reviews, see, e.g., Hillman, Keim, and Schuler, 2004; Stratmann, 2005). The literature suggests that corporate political spending is highly profitable, earning margins above what would be expected in a competitive market and raising a "puzzle" of "astronomically high average rates of return on [political] investment" (Ansolabehere, de Figueiredo, and Snyder, 2003, p. 111; also see, Tullock, 1972). However, most of the returns cited as evidence for this puzzle are based on descriptive and univariate statistics - for example, by comparing the size of total government expenditures to aggregate campaign and lobbying spending by firms. The literature offers few, if any, rigorous estimates of returns to corporate political spending. There are two main reasons for this void. First, the benefits from legislation and regulation are usually indirect, long-term, and thus difficult to isolate. Second, it is difficult to identify that part of corporate political spending that represents an "investment" on which a return can be estimated. After all, there are other reasons for corporate political spending, including managerial consumption.

In this paper, we exploit the setting of the 2004 passage of the American Jobs Creation Act (hereafter, AJCA or "the Act") to overcome in part these empirical challenges to estimating a return on corporate political spending. The AJCA, among other provisions, offered U.S. firms a one-time tax break of up to $29.75 \%$ on accumulated foreign income repatriated and invested in U.S.-based capital projects. Such repatriation was required to be completed by the year following the Act's passage, making it unlikely 
that firms adjusted real activities to take advantage of the Act. Moreover, repatriating firms had to disclose in their audited financial statements the precise amount repatriated under its provisions. These two features of the Act enable us to determine the benefits to firms from the repatriation-tax holiday in the Act, thus addressing the first of two key challenges to estimating returns to political spending.

To overcome the second challenge to determining political returns, i.e., estimating the investment firms made to effect the repatriation-tax holiday's passage through Congress, we need a method to parse this investment from a firm's total political spending. To this end, we exploit the fact that prior published research has already investigated the incentives of firms repatriating under the Act. Specifically, Blouin and Krull (2009) provide an economic model of the determinants of firms' repatriation under the Act. We expect that these economic forces that drive repatriation under the Act (e.g., a high effective U.S.-tax rate) also determine firms' political spending to secure the repatriation-tax holiday's passage. Accordingly, we estimate through a regression the component of a firm's total political spending that is driven by these economic determinants, a value that we refer to as the firm's "predicted political spending." We then run a second regression where a firm's repatriation under the Act is the dependent variable and "predicted political spending" is the explanatory variable of interest. The coefficient on "predicted political spending" in this second regression provides a marginal estimate of benefits to firms from incremental political spending to secure the passage of the Act's repatriation-tax holiday.

It is plausible, of course, that Blouin and Krull's economic model of firms' repatriation, like any empirical model of this nature, does not include all relevant 
explanatory variables. In this case, the second regression above suffers from an omittedvariable bias, where the dependent variable (repatriations) and "predicted political spending" are jointly affected by omitted variables. To address this issue, we employ an instrumental-variable approach. That is, we use as an instrument in the first regression a variable that predicts firms' political spending on the repatriation-tax holiday in the Act but that does not directly predict repatriations. Our instrument is the degree of political conservatism of the congressperson historically receiving the most contributions from a given firm. The historical level of PAC contributions between firm and congressperson can proxy for the relationship between the two (Snyder, 1992), so the congressperson with the most PAC receipts can be inferred to have a strong relationship with the firm. That congressperson's ideology - measured over a conservative-liberal spectrum - can instrument for the firm's tax-related political spending. The premise here is that the more conservative a firm's congressional ally, the less tax-related political spending necessary by the firm because conservative politicians are ideologically more predisposed to support legislation on lower taxes.

Importantly, the historically allied congresspersons' ideology is not expected to directly predict repatriations because the firm-politician ties are expected to predate lobbying on the repatriation-tax holiday. This argument is supported by the legislative history of the repatriation-tax holiday in the AJCA. The Act was precipitated in part by European Union (EU) sanctions imposed in 2004 against certain U.S. export subsidies that the World Trade Organization (WTO) had ruled illegal. As Congress began the process to repeal the subsidies (and thus obviate the EU sanctions), questions were raised about how to redeploy the approximately $\$ 50$ billion in savings that the U.S. Treasury 
would save as a result. It was in this climate that firms and their lobbyists actively pitched ideas for various corporate tax breaks, including a repatriation-tax holiday. Notably, prior to the EU sanctions and the public savings generated by repealing associated U.S. export subsidies, there was little political scope in Congress for corporate tax relief, in part due to large prevailing public deficits driven by war-time spending. In mid-2004, as the passage of some form of corporate tax relief became more likely, firms with accumulated overseas income lobbied for a repatriation-tax holiday. It is the return on political investment of these firms that we estimate in our study.

The estimates from our regression model suggest that for the median U.S. firm with long-term political relationships at the time of the Act's passage, an additional investment of $\$ 1$ million in lobbying expenditures is associated with $\$ 32.35$ million in taxes saved on repatriated foreign income. These estimates appear to be high relative to returns earned in competitive markets and are, in fact, consistent with there being a "puzzle" in returns to political investment. But, these estimates are considerably lower than those generated through descriptive methods. For example, Alexander, Scholz, and Mazza (2009), the only other study of which we are aware that attempts to measure returns to political spending on the AJCA, conclude that firms lobbying for the repatriation-tax holiday in the Act "have a return in excess of $\$ 220$ for every $\$ 1$ spent on lobbying." Their estimate, which has been widely referenced in the press (e.g., Eggen, 2009; Newman, 2011) and some academic work (e.g., Lessig, 2011), is essentially based on a univariate analysis - by aggregating the estimated tax savings of all firms repatriating under the Act and dividing by the lobbying expenditures of those firms. Thus, we argue that our study represents an improvement on the measurement of political 
returns to the repatriation-tax holiday in the AJCA and, in doing so, offers some insight into the margin of error embedded in estimates of returns to political spending obtained via descriptive methods.

To conduct our study, we first identify the initiation of legislative action that eventually directly led to the passage of the AJCA. The first such legislative action was during the $108^{\text {th }}$ Congress $(2003-2004)$. We next identify the sample of politically active U.S. firms with a history of at least five years leading up to 2003 - such firms are more likely to have the long-term relationships in Congress necessary to effect passage of the Act (e.g., Snyder, 1992). Then, we select only those firms operating overseas, since only such firms would be directly affected by a repatriation-tax holiday. Finally, we calculate the increase in political spending among these firms during the tenure of the $108^{\text {th }}$ Congress, which passed the Act (the increase is calculated over spending during the $107^{\text {th }}$ Congress, 2001-2002). We focus on changes in political spending because levels of spending, much like corporate dividends, can be sticky.

We measure corporate political spending on the repatriation-tax holiday in the Act in three ways. First, we look at increases in contributions from firms' political action committees (PAC) to members of Congress - these are usually direct contributions to the members' individual campaign funds. Second, we look at increases in firms' lobbying expenditures, which include corporate political spending on conferences, dinners, and other "informational events" where corporations advance their agenda with politicians and their staff. Finally, to isolate corporate political spending specifically related to taxes, we look at increases in lobbying disclosure reports of the same - that is, increases in the number of tax-related lobbying reports connected to a given firm. These three measures 
capture different aspects of corporate political investment and are often used concurrently by firms.

As already noted, we find that for the median firm in our sample an increase of $\$ 1$ million in lobbying contributions (over the firm's prior cycle contributions) is associated with $\$ 32.35$ million in taxes saved on repatriated foreign income. Relatedly, we find that an increase of $\$ 100,000$ in PAC contributions is associated with about $\$ 15.64$ million in taxes saved and that the additional filing of ten tax-related lobbying reports is associated with about $\$ 21.08$ million in taxes saved. The differences in return estimates across the three measures of corporate political spending can be at least partly attributed to the fact that each measure captures a somewhat different aspect of such spending. ${ }^{1}$ But, as prior political science research has shown, firms generally use these various methods of political spending in complement with each other (Ansolabehere, Snyder, and Tripathi, 2002). Thus, it is likely more meaningful to consider the three return estimates jointly.

Our results should also be interpreted in the context of the following observation. We focus on political investments for a repatriation-tax holiday during a single congressional cycle, 2003-2004. We do not consider political investments on this issue that firms may have made in prior cycles. To the extent that these prior investments also contributed to the repatriation-tax holiday's passage in 2004, our return estimates are biased upward. The legislative history of the repatriation-tax holiday in the AJCA (briefly summarized earlier and discussed in greater detail in Section 2) mitigates this concern to some extent. Moreover, our empirical strategy, which is focused primarily on changes in political spending in the 2003-2004 cycle, is intended to further forestall this concern. As

\footnotetext{
${ }^{1}$ Further, the size of PAC contributions, unlike lobbying spending, was limited by law during at that time.
} 
such, our regressions estimate the marginal benefit of an incremental dollar of political spending in the 2003-2004 period, above that routinely spent to maintain ties with politicians. In this sense, our method for estimating political returns is designed to generate upper-bound estimates of the "true" return value.

In addition to contributing to the literature on returns to corporate political spending by providing more careful estimates of the returns, our study adds to the literature on corporate taxation. Our results are particularly relevant in light of continued corporate attempts to generate support in the Congress for another "one-time" tax break on repatriated foreign income in line with the AJCA of 2004 (e.g., Worstall, 2013; Stephenson and Temple-West, 2014). As of 2013 U.S. companies are estimated to have stockpiled nearly $\$ 1$ trillion in cash overseas (e.g., Waters, 2014), and such stockpiling is sometimes attributed by the press to the companies' desire to avoid taxation in the United States (e.g., O'Brien, 2014). As companies have ramped up their political spending for another tax holiday on repatriations, our study provides some perspective on how this renewed corporate political investment could pay off. Specifically, our study suggests that the very high returns to political investment heralded in the press - obtained through descriptive methods - are, in fact, nearly an order of magnitude smaller when more rigorously estimated via instrumentation.

The remainder of this paper is organized as follows. Section 2 provides some background to the passage of the 2004 American Jobs Creation Act and describes relevant research. Section 3 details our research design, including our choice of instrument. Section 4 describes the results. Section 5 concludes. 


\section{Background and related research}

The AJCA of 2004 has its origins in a WTO ruling that a certain U.S. subsidy for exports by U.S.-based companies was illegal. The subsidy was known as the extraterritorial income (ETI) exclusion. The WTO ruling invited tariffs by the EU against imports from the U.S. subject to the ETI exclusion. Starting in March 2004, the EU began imposing a five percent tariff on associated U.S. imports, with a planned one percent increase per month, as a way to force the U.S. to repeal the ETI exclusion. As U.S. exporters began to feel the costs of the EU tariffs, pressure began to build in Congress to repeal the ETI exclusion. A related discussion among lobbyists and congresspersons was what to do with the approximately $\$ 50$ billion the U.S. Treasury was expected to net from the ETI-exclusion repeal. A number of interested firms (and their lobbyists) began arguing for a holiday on taxes owed on accumulated overseas income.

The United States is among a handful of countries that taxes its citizens and corporations on worldwide income. However, in general, corporations can delay paying taxes on foreign income until such income is repatriated to the United States. This situation has from time-to-time resulted in large build-ups of accumulated overseas income by U.S. corporations. One such time period was the early 2000s. The weak economy and high unemployment of the period raised the visibility of U.S. corporations' accumulated overseas income. But prior to the WTO's ruling and associated EU sanctions (during the 2003-2004 congressional cycle), the likelihood of congressional passage of a tax break for corporations - such as a tax holiday for repatriated corporate income - was relatively low. Growing public deficits driven by U.S. military action in the Middle East made further charges to the exchequer politically difficult. However, the 
sudden emergence of $\$ 50$ billion in savings to the U.S. Treasury from the ETI-exclusion repeal raised the possibility that these savings could be applied to fund corporate tax relief of some form.

The increasing trend of corporate outsourcing to offshore destinations created additional impetus for tax-policy changes that would encourage U.S.-based corporate investment. The looming general election of 2004 provided a sense of urgency as politicians spoke of an act to "make our manufacturing, service, and high-technology businesses and workers more competitive and productive both at home and abroad" (U.S. House, 2004). While the adoption of broad-based corporate tax relief was considered difficult during the 2001-2002 congressional cycle, by the summer of 2004 Congress was ready to pass such legislation.

It was not obvious that congressional legislation for corporate tax relief in 2004 would include a tax holiday on repatriated income. Export-oriented American firms that did not have substantial overseas operations (and thus, did not have significant accumulated overseas income) had their own proposals for how the savings to the exchequer from the ETI exclusion repeal should be deployed. These firms lobbied for domestic manufacturing tax subsidies instead.

The inclusion of a repatriation-tax holiday in the AJCA of 2004 was a process involving the participation of many corporate interest groups. ${ }^{2}$ For example, more than fifty multinational companies (including Apple, Altria, Eli Lily, Hewlett Packard, and Intel) formed a coalition called the Homeland Investment Act Coalition (HIAC) to lobby for the repatriation-tax holiday. The HIAC's position was supported by another group

\footnotetext{
${ }^{2}$ See Alexander et al. (2009) for a review of the events surrounding the passage of the Act.
} 
called the Coalition for Fair International Taxation, which represented over thirty multinational firms such as Bank of America, GE, and Wal-Mart. Later, in Section 3, we attempt to systematically construct the sample of firms that were likely lobbying for the repatriation-tax holiday in 2004. It is on this sample that we measure returns to political investment.

Eventually, firms lobbying for a repatriation-tax holiday were successful in securing its inclusion in the AJCA. That Act also included a tax deduction for income from U.S. production activities, suggesting that the export-oriented domestic manufacturers without accumulated overseas income were also successful in their lobbying efforts. ${ }^{3}$

The repatriation-tax holiday in the Act has been controversial. This controversy stems from a provision in the Act that repatriated income be deployed toward domestic investment and job creation rather than equity and management-compensation payouts. Supporters of the repatriation-tax holiday argue that it brought overseas money back to the U.S. and helped create jobs, while its opponents claim corporations used the "repatriated money to buy up their own stock rather than to expand or create jobs" (McKinnon, 2009). Blouin and Krull (2009) find evidence that firms that repatriated under the Act had lower investment opportunities and higher free cash flows than nonrepatriating firms. Further, repatriating firms increased their share repurchases by nearly $\$ 60$ billion more than a matched-sample of non-repatriating counterparts. Their results

\footnotetext{
${ }^{3}$ Estimating the return on political spending for this group of firms seeking domestic manufacturing tax subsidies is more difficult for a number of reasons. First, the benefits from these subsidies are likely to be accrued over many years. Second, these firms' future manufacturing activities are likely to be affected by the subsidies, making the benefits endogenous to the Act's passage.
} 
are corroborated by the findings of a survey conducted on corporate tax executives (Graham, Hanlon, and Shevlin, 2010). Dharmapala, Foley, and Forbes (2011) also find similar results: they show for every one-dollar increase in firms' repatriation, there is a $\$ 0.60$ to $\$ 0.92$ increase in their payout to shareholders. Relatedly, Faulkender and Peterson (2012) find no increases in domestic investment for repatriating firms without capital constraints, although they also find "little change" in such firms' equity payouts. Oler, Shevlin, and Wilson (2007) find shareholders anticipated the tax savings related to the Act: repatriating firms' stock prices reflected the potential savings even prior to the passage of the Act.

Different from the studies above, this paper does not draw conclusions on the effectiveness of the repatriation-tax holiday. Rather, the primary purpose of this paper is to offer more robust estimates of the returns to political spending. Ansolabehere at al. (2003, p. 111) summarize findings of "astronomically high rates of return" to political investments, but much of the evidence marshaled on this point is descriptive in nature. Beyond the descriptive evidence, there are some event studies of firms' stock-market returns to certain exogenous political incidents - e.g., the death of a senator (Roberts, 1990) or the unexpected cross-party defection of a senator (Jayachandran, 2006). These events studies offer some insight into the sensitivity of firm value to the political incidents in question. But inferring returns to firms' prior political investment from such event studies is at best indirect. In addition to the event studies, there are a handful of association studies documenting long-run correlations between corporate political spending and future firm performance (e.g., Cooper, Gulen, Ovtchinnikov, 2010). But such association studies often lack compelling identification strategies, so the 
documented correlations cannot be attributed to an investment-return relation. ${ }^{4}$ Moreover, there is no conceptual basis to determine the horizon over which returns to political spending should be measured in these studies, so decisions to this effect are arbitrary, and the return estimates generated are ad hoc.

Prior literature has encountered two main challenges in estimating returns to political investment: quantifying the precise benefits from a given legislation or regulation; and determining the precise investment in political spending to attain that specific benefit. Using the AJCA setting allows us to quantify the benefit because firms are required to disclose in audited reports the precise amount repatriated. We also use a novel instrument to isolate the increase in political spending, i.e., the political investment, specifically attributable to the repatriation-tax holiday in the AJCA. As such, our setting and research methodology allow us to more rigorously estimate an upper bound for the returns to political spending.

The only other study to estimate the return on political spending to the repatriation-tax holiday in the AJCA is Alexander et al. (2009). That study simply aggregates the estimated tax savings of all firms repatriating under the Act and divides by the lobbying expenditures of these firms (see, in particular, Section III B and Table 6 of Alexander et al.). The return estimate in Alexander et al. does not address the central challenges in estimating the returns to political spending.

Our effort at estimating returns to political spending on the repatriation-tax holiday in the AJCA is also relevant given renewed interest in a tax provision similar to

\footnotetext{
${ }^{4}$ There are other reasons (besides an investment-return relation) to expect positive long-run correlations between corporate political spending and future firm performance - e.g., managers of well-performing firms could engage in political spending as a form of personal consumption.
} 
the 2004 Act. In 2011, several influential companies, including Apple, Cisco, Google, and Microsoft, formed a lobbying coalition to push for another tax break on repatriated earnings (e.g., Eggen, 2011; Rubin, 2012). These companies spent $\$ 760,000$ on the initiative before ceasing their efforts in March 2012 after realizing there was little political will behind the issue that year (e.g., Rubin, 2012). But starting 2013, there has been further debate for another bill like the American Jobs Creation Act of 2004. In 2013, Apple's CEO, Tim Cook, testified to the Senate Permanent Subcommittee on Investigations and called on Congress to reduce taxes on repatriated earnings to the single digits (e.g., Hook and Yadron, 2013). At that time Cook revealed that Apple had $\$ 100$ billion in offshore earnings that he was not willing to bring back to the U.S. under the current tax rate. In 2014, several influential U.S. senators expressed support for eliminating or reducing the U.S. tax rate on repatriated income. These senators included Ron Wyden (chair of the Senate Finance Committee), Harry Reid (Democratic Majority Leader), and Rand Paul (potential Republican presidential nominee in 2016) (e.g., Murphy, 2014; Pozen, 2014).

The results of this paper can add to the literature on the American Jobs Creation Act of 2004 and to the broader literature on business engagement in the political process by providing a more careful estimate of returns to political spending on tax issues. This contribution is relevant to both academia (given the limited empirical evidence on the subject) and public policy (given the current interest in another tax break on repatriations). 


\section{Research design}

In this section, we detail our research design for generating estimates of the return to political spending on the repatriation-tax holiday in the AJCA. For such estimates, we need to establish a statistical link between repatriation under the Act and political spending for the reduced tax on repatriations. To do so, we begin by identifying the sample of politically active firms in the United States that were in existence during the period in which firms could repatriate under the Act. We define a firm as "politically active" if it has at least one active PAC in the period of interest. By this definition, there are 1,400 politically active firms on COMPUSTAT in the year 2006, which is the last possible year for firms to repatriate under the Act. Next, we restrict this group of firms to those that could avail of their political relationships to effect the Act's passage. The first congressional event related to the Act's passage was during the $108^{\text {th }}$ Congress (20032004), so ordinarily we would restrict the sample of 1,400 politically active firms to those around from 2003. But, prior research in political science has shown that usually firms must be involved with politicians over an extended period of time for the firms to reap benefits from that relationship (e.g., Snyder, 1992). Accordingly, we limit our sample to firms with at least five years of history at the time of the initiation of the $108^{\text {th }}$ Congress. That is, our sample consists of politically active U.S. firms operating at least since 1998 and at least through 2006. There are 880 such firms in COMPUSTAT. Finally, we restrict this group to only firms operating overseas, since only such firms would be directly affected by the repatriation-tax holiday in the Act. This restriction yields a sample of 513 firms. Subsequent data requirements necessitated by our multivariate regressions, described shortly, reduce this sample to 511 firms. 
In this sample, we measure changes in corporate political spending during the tenure of the $108^{\text {th }}$ Congress, which passed the AJCA. The changes are calculated relative to political spending during the preceding $107^{\text {th }}$ Congress (2001-2002). We measure corporate political spending in three ways. First, we look at changes in sample firms' PAC contributions. Here, PAC contributions refer to aggregate donations made by the political action committee(s) associated with a specific sample firm to members of Congress. The PAC data are obtained from the Center for Responsive Politics (CRP), which compiles the information from the Federal Election Commission (FEC). All PACs must file quarterly or monthly reports disclosing their receipts and disbursements with the FEC. ${ }^{5}$ Prior political science research using changes in political spending note the highly skewed (non-normal) distribution of these data (e.g., Ansolabehere et al., 2002). Such studies usually employ a cube-root transformation of the changes data (rather than the log transformation more common in finance research) - the cube-root transformation normalizes the distribution without causing a problem for cases of zero changes in political spending (which are common). Thus, our proxy for changes in sample firms' PAC contributions is the cube root of the difference between the values for the $108^{\text {th }}$ and $107^{\text {th }}$ Congresses.

Our second measure of corporate political spending is firms' lobbying expenditures. These expenditures are distinct from PAC contributions, which are focused on election campaigns. Lobbying expenditures represent firms' spending on registered lobbyists (including retired politicians) and related activities, including conferences and other events where corporations can advance their agenda with politicians and their staff.

\footnotetext{
${ }^{5}$ The CRP's data are available at www.opensecrets.org.
} 
As with PAC contributions, when measuring the change in lobbying expenditures from the $107^{\text {th }}$ to the $108^{\text {th }}$ Congress, we use the cube root of the difference as our final proxy. We obtain firms' lobbying expenditures from the CRP, which compiles the data from reports filed with the Senate Office of Public Records. Since the passage of Lobbying Disclosure Act of 1995, organizations involved in lobbying activities at the federal level are required to file semi-annually with the Senate information on their lobbying-related expenditures.

Changes in PAC contributions and lobbying expenditures can be associated with political causes not related to taxes. Our third measure of corporate political spending intends to capture the intensity of lobbying specifically associated with tax issues. Specifically, we measure for our sample firms the change in the number of lobbying reports identifying taxes as a lobbied issue. Every organization (registered lobbyist) that receives money from a firm to lobby on its behalf must file a report with the Senate under the Lobbying Disclosure Act. The reports, which are standardized, contain information on the lobbyist's client account, including the client's name, the aggregate lobbying amount, and the issues lobbied on. We use the data in these reports to determine for each sample firm the number of lobbying reports that identify tax as a lobbied issue. For example, Appendix A provides the report William and Jensen, PC, filed for its $\$ 260,000$ lobbying efforts on behalf of Dell for the second half of 2004. The report provides information on the general issues on which William and Jensen lobbied on behalf of Dell - federal appropriations, homeland security, Navy Marine Corps Intranet programs, cyber security, and tax issues. For 2004, there are five reports like the one in Appendix A filed with respect to Dell that disclose lobbying focused on tax. We use the annual number of 
reports that disclose tax as a lobbying issue as our proxy for the intensity of lobbying specifically associated with tax issues.

We conduct this procedure for both the $107^{\text {th }}$ and $108^{\text {th }}$ Congresses to determine the change in the number of tax-related lobbying reports for sample firms. As with PAC contributions and lobbying expenditures, when measuring changes in the number of taxrelated lobbying reports, we use the cube root of the difference between the values for the $108^{\text {th }}$ and $107^{\text {th }}$ Congresses as our final proxy.

The advantage to this third measure of corporate political spending is that it focuses specifically on taxes. Of course, increases in tax-related lobbying reports during the $108^{\text {th }}$ Congress could be for reasons unrelated to the repatriation holiday that was eventually codified in the AJCA. To investigate this concern, we examine every tax law that was passed by the $108^{\text {th }}$ Congress as well as every tax bill that made it at least to House floor action to identify any potential concurrent tax events. ${ }^{6}$

We obtain the tax law and tax bill information from the congressional Online library at www.thomas.loc.gov. There are forty-one tax bills that made it at least to House floor action during the $108^{\text {th }}$ Congress. Of these, twenty bills were passed by the Senate and sixteen were signed by the president into law. Panel A of Appendix B presents the breakdown of tax bills by the last stage achieved in the legislative process. Panel B of Appendix B presents the breakdown of the same forty-one bills by major issue. The data reveal that the majority of the tax bills were concerned with personal-level taxes. Several of the remaining tax bills potentially affected corporate taxes, but these bills largely focused on specific industries, such as transportation or healthcare. The only bill during

\footnotetext{
${ }^{6}$ We limit bills to House floor action because constitutionally the House must introduce legislation on taxrelated issues before the Senate considers it.
} 
the $108^{\text {th }}$ Congress that broadly concerns corporate income tax is the American Jobs Creation Act.

\subsection{Regression design and instrumentation}

Estimating the return on political investments over the repatriation-tax holiday in the AJCA for our sample firms involves identifying that component of repatriations under the Act that can be attributed to increased political spending on a lower repatriation tax. One method to do so is to simply regress repatriations under the Act on increased political spending, controlling for the economic determinants of repatriation. The problem with this approach is that there can be numerous reasons for increased political spending that are unrelated to repatriation-tax lobbying. To address this problem, we attempt to identify in a preceding regression ("the first stage") that component of increased political spending that can be attributed to promoting a repatriation-tax holiday. We use the model for the economic determinants of repatriation provided by Blouin and Krull (2009) in this first-stage regression - the assumption being that the same variables that predict repatriation under the Act also predict lobbying for the repatriation-tax holiday in the Act. We call the component of increased political spending attributed to the repatriation-tax holiday in the first-stage regression the "predicted political spending" (or Polıtıcal Spending). Then, in a primary regression ("the second stage"), where repatriation under the Act is the dependent variable, we estimate the coefficient on "predicted political spending."

The Blouin and Krull model (like any empirical model of this nature) can be incomplete, resulting in an omitted-variable bias in the second-stage regression. Put differently, if the model of economic determinants of repatriation under the Act (and 
lobbying for the repatriation-tax holiday) is incomplete, both the dependent variable and "predicted political spending" in the second-stage regression are influenced by omitted correlated variables. Estimates from such a regression will be biased. To address this issue, we instrument for political spending in the first-stage regression using a variable we call AllyIdeology.

For a given firm, AllyIdeology is the value of congressional ideology for the congressperson receiving the most contributions from that firm in the 2001-2002 congressional cycle (i.e., the prior cycle to the $108^{\text {th }}$ Congress). Here, "congressional ideology" is the first dimension of the widely used Common Space Score developed by Keith Poole and collaborators and available on Poole's website, www.voteview.com (e.g., Poole, 1998). The level of PAC contributions between firm and congressperson during the preceding $107^{\text {th }}$ Congress can proxy for the relationship between the two, so the congressperson with the highest PAC contributions can be inferred to have a strong relationship with the firm. AllyIdeology measures how receptive a firm's (historically most contributed to) congressional ally is to a reduced tax on repatriations. Ceteris paribus, the more conservative the congressional ally, the less the firm will have to spend on lobbying for lower taxes (since conservatives are more likely to favor lower taxes). AllyIdeology can make a good instrument in our setting because it is likely to predict political spending on taxes but is unlikely to be jointly determined with repatriations under the Act. This is because the relationship with the congressperson in question is expected to precede lobbying for the repatriation-tax holiday under the Act. Recall from Section 2 that it was only during the 2003-2004 congressional cycle - after the EU imposed sanctions on certain U.S. exporters and Congress considered repealing certain 
export subsidies - that passage of a broad-based corporate tax break, including a repatriation-tax holiday, became realistic. ${ }^{7}$

The predicted value of political spending from the first-stage regression using AllyIdeology as the instrument is used in the second-stage regression of repatriations under the Act. In other words, we estimate the following two regressions in our sample of firms.

$$
\begin{aligned}
& \text { Political Spending }=\eta_{0}+\eta_{1} * \text { AllyIdeology }+\eta_{\{\ldots\}} *\{\text { Controls }\}+\varepsilon_{1} \\
& \text { Repatriation }=\lambda_{0}+\lambda_{1} * \text { Polıtıcal Spending }+\lambda_{\{\ldots\}} *\{\text { Controls }\}+\varepsilon_{2}
\end{aligned}
$$

In the above system of equations, Political Spending refers to one of the three proxies described earlier: (i) the cube-root transformation of the change in PAC contributions (hereafter, $\triangle \mathrm{PAC}$ ); (ii) the cube-root transformation of the change in lobbying expenditures (hereafter, $\Delta$ Lobbying); and (iii) the cube-root transformation of the change in the number of tax-related lobbying reports (hereafter, $\Delta$ Tax Reports).

Repatriation in equation (2) is the dollar amount of repatriation under the Act, scaled by firm assets. Data on firms' repatriation decisions, including the amount repatriated, are manually collected from 10-K filings in which such disclosures are required. We search sample firms' $10-\mathrm{K}$ filings during the years immediately following the Act's passage for repatriation information. Since Repatriation is left censored at zero, we use a Tobit model in equation (2). Equation (1) is estimated using ordinary least squares.

\footnotetext{
${ }^{7}$ Related to this argument, we use contributions during the $107^{\text {th }}$ Congress (rather than the $108^{\text {th }}$ ) to compute AllyIdeology because firms could have ramped up contributions during the $108^{\text {th }}$ Congress to certain congresspersons with particular sway over the AJCA's passage (e.g., House or Senate leaders). If so, such a congressperson's ideology is not sufficiently exogenous for our purposes.
} 
The set $\{$ Controls $\}$ in the above equations constitutes the factors identified by Blouin and Krull (2009) as the economic determinants of repatriation. The Blouin and Krull study "investigates the characteristics of firms that repatriate under the Act," so their model of the determinants of repatriations is well suited to our purposes. Specifically, Blouin and Krull (2009) argue firms that repatriate are more likely to have declining investment opportunities and a higher level of free cash flows in the years prior to the passage of the Act. Thus, the set $\{$ Controls $\}$ includes variables to this effect. The full list of controls and their definitions are given below.

$\triangle R O A \quad$ the change in net income scaled by worldwide assets for the period 2001 to 2004

$\triangle M B \quad$ the change in the firm's market value to book value ratio for the period 2001 to 2004

$\triangle R D \quad$ the change in the ratio of research and development expenses to worldwide assets for the period 2001 to 2004

$\triangle C A p E x \quad$ the change in capital expenditures divided by worldwide assets for the period 2001 to 2004

FCF the average operating cash flows divided by worldwide assets for the period 2001 to 2004

USTR the average U.S. tax rate from 2001 through 2004

$\triangle F P T I \quad$ the change in foreign pre-tax income scaled by worldwide assets

RateDum a dummy variable set to one if the U.S. tax rate of $35 \%$ exceeds the average foreign tax rate from 2001 to 2004 , zero otherwise 
$\%$ FAssets the ratio of foreign assets (estimated as described in Oler et al., 2007) to worldwide assets

Among the variables above, $\triangle R O A$ and change in foreign pre-tax income ( $\triangle F P T I)$ are included to control for financial performance, $\triangle M B$ to control for growth opportunities, $\triangle R D$ to control for change in research and development, and $\triangle C a p E x$ to control for change in capital expenditures. All these variables capture elements of firms' declining investment opportunities. $F C F$ is included to control for the level of free cash flows. Blouin and Krull also conjecture that firms with a high U.S. domestic tax burden, proxied by USTR and RateDum, are more likely to receive benefits by repatriating under the Act. All of the data necessary to construct these variables are obtained from COMPUSTAT.

The value of the coefficient $\widehat{\lambda_{1}}$ in equation (2) is our estimate of the component of repatriations under the Act that can be attributed to political spending on a reduced tax on repatriations.

\section{Results}

\subsection{Univariate analyses}

Before presenting the results of the regressions described in the previous section, here we lay out some descriptive statistics on our sample firms. Table 1 presents summary statistics for changes and levels in political spending for our sample firms. For comparison, this table includes a separate sample of the 367 politically active U.S. firms during our period of interest (that is, at least since 1998 and at least through 2006) that did not operate overseas. (Collectively, these 367 firms and our sample of 513 firms 
make up the 880 firms described at the beginning of Section 3.) For our 513 sample firms (with overseas operations), the mean values of changes in political spending across our three proxies are as follows: $\$ 21,401$ for PAC contributions; $\$ 292,753$ for lobbying expenditures; and 0.66 for tax-related lobbying reports. (To facilitate interpretation, the reported values in Table 1 have not been subject to cube-root transformation). The corresponding values for the 367 firms without overseas operations are $\$ 13,993$ for PAC contributions, $\$ 72,899$ for lobbying expenditures, and 0.15 for tax-related lobbying reports. The differences in means for lobbying expenditures and tax-related lobbying reports - but not PAC contributions - are statistically significant.

The mean levels of political spending (during the $108^{\text {th }}$ Congress) for the 513 sample firms are $\$ 118,569$ for PAC contributions, $\$ 1,360,077$ for lobbying expenditures, and 2.97 for tax-related lobbying reports. The corresponding mean levels of political spending for the 367 firms without overseas operations are $\$ 62,592$ for PAC contributions, $\$ 323,171$ for lobbying expenditures, and 1.05 for tax-related lobbying reports. The differences in mean levels across all three proxies are statistically significant. Table 1 also presents the median values of all of the variables discussed above. With the exception of levels and changes in PAC contributions, the median values are zero. This right skew in the distribution of the data is common to other studies using political spending proxies. Overall, the data from Table 1 suggest that our sample firms (those with overseas operations) exhibit higher levels and changes in political spending relative to politically active domestic firms.

Table 2 presents the correlations between the various proxies for political spending. The correlations for both levels and changes in those proxies are reported. The 
correlations are calculated in our sample of 513 firms. The three different proxies for firms' political spending show significantly positive correlation with each other in both levels and changes. This is consistent with prior evidence in the political science literature suggesting that PAC contributions and lobbying expenditures are often used in complement with each other as part of a firm's integrated political-engagement strategy (e.g., Ansolabehere et al., 2002).

Table 3 presents summary statistics for Repatriation and the various control variables used in the system of equations described in the prior section. The summary statistics are computed across our sample of 513 firms, subject to data availability (we lack the data required to calculate control variables for two of the firms). The mean value of Repatriation is 0.021 , which suggests that the average firm repatriates about $2.1 \%$ of its assets under the Act. The median value of Repatriation is zero. Of particular interest, the mean and median values of AllyIdeology are 0.150 and 0.236 , respectively. The first dimension of Common Space Scores, which AllyIdeology represents, is scaled between +1 and -1 , where positive values suggest political conservatism and negative values political liberalism. Thus, the mean and median values for AllyIdeology in our sample suggest that the congresspersons receiving the most contributions from our sample firms during the 2001-2002 congressional cycle tend to be, on average, more conservative than liberal.

\subsection{Multivariate analyses}

Table 4A reports results from the first-stage regression, i.e., the regression summarized in equation (1). Here, our three proxies for changes in corporate political spending $-\Delta$ PAC, $\Delta$ Lobbying, and $\Delta$ Tax Reports - serve alternatively as the 
dependent variable. The instrumental variable AllyIdeology has a negative and significant coefficient in all three regressions specifications in Table 4A. The results are consistent with our expectation that firms historically connected to more conservative politicians in the Congress give less in the period they lobby for lower taxes on repatriated foreign income. We expect this result because conservative politicians are ideologically more predisposed to lower taxes.

We also perform a weak-instrument test to check the suitability of our instrumentation approach in Table 4A. Stock, Wright, and Yogo (2002) recommend the value of the F-statistic from the test be above 8.94 for a single instrument to be considered valid. The F-statistics in the three regressions of Table 4A are 10.21, 2.79, and 13.06, respectively; the F-statistics suggest that all but the change in lobbying expenditures pass the Stock et al. test.

The results of the second-stage regression are reported in Table 4B. The regression specification is described in equation (2). Since the regression is a Tobit model, parameter estimates cannot be directly interpreted for substantive significance. Accordingly, in lieu of parameter estimates, we report marginal effects; the p-values reported below the marginal effects refer to the statistical significance of the underlying parameter estimates.

The coefficient on the variable Political Spending, which captures the return on political spending, is positive and statistically significant (at the $90 \%$ confidence level) in all three specifications of Table 4B. The result indicates that repatriations under the Act are associated with higher levels of political spending in the period leading up to the Act, 
after instrumenting for such spending. In the following section, we interpret the substantive significance of this result.

The control variables in the regressions in Table 4 are the set of economic determinants of repatriation identified in Blouin and Krull (2009). Blouin and Krull argue firms that repatriate are more likely to have declining growth opportunities, decreasing research and development $(\mathrm{R} \& \mathrm{D})$ and capital expenditures, and a higher level of free cash flows in the years prior to the passage of the Act. Following Blouin and Krull, we include $\triangle R O A$ and $\triangle F P T I$ to control for financial performance, $\triangle M B$ for growth opportunities, $\triangle R D$ and $\triangle C a p E x$ for change in $\mathrm{R} \& \mathrm{D}$ and capital expenditures, and $F C F$ for free cash flows levels. They also conjecture firms with a high U.S. domestic tax burden, proxied for by USTR and RateDum, are more likely to receive more benefits by repatriating under the Act.

In estimating the determinants of repatriation (second stage), we find the coefficients on $\triangle R O A, \triangle M B, \triangle C a p E x$, and $\triangle F P T I$ are not statistically significant. However, the coefficient on $\triangle R D$ is negative and statistically significant and that on $F C F$ is positive and statistically significant across all model specifications, as predicted by Blouin and Krull. The results suggest that firms with decreased R\&D spending and increased free cash flows are more likely to repatriate under the Act. We also find that the variables USTR and RateDum are significantly and positively associated with repatriations, suggesting firms with a high U.S. tax burden are more likely to repatriate. These results are also consistent with those in the Blouin and Krull study.

Tables 5A and 5B report the regression results using the levels of our three proxies for corporate political spending in lieu changes. Here, as with the changes, we 
use the cube-root transformation of the values to adjust for their non-normal distribution. Using the levels of political spending can be more meaningful in computing political returns since the levels represent the total political investment in a given period. The results are similar to those using changes. Table $5 \mathrm{~A}$ reports results of the first-stage regressions. The instrumental variable AllyIdeology has a negative and statistically significant coefficient in all three of these regressions. This result is consistent with our expectation that firms historically contributing to conservative members of Congress give less in the period in which they lobby for lower taxes. The F-statistics in the three regressions of Table 5A are 39.19, 39.59, and 52.23, respectively, suggesting all specifications pass the Stock et al. weak-instrument test.

The coefficient on the variable Polıtıcal Spendıng, which attempts to capture the return on political spending, is positive and statistically significant in all three specifications of Table 5B, the second-stage regression. The results indicate that repatriations under the Act are associated with higher levels of political spending in the period leading up to the Act, after instrumenting for such spending. Apropos the control variables in the second stage, the coefficient on $\triangle R D$ is negative and statistically significant while the coefficients on FCF, USTR, and RateDum are positive and statistically significant across all model specifications. These results are consistent with Table 4B and the predictions in the Blouin and Krull study. As in Table 4B, we find insignificant coefficients on $\triangle R O A, \triangle M B, \triangle C a p E x$, and $\triangle F P T I$.

\subsection{Computing the return on political investment}

To compute the return on political investment from Table 4B, we examine the marginal effect of Polıtıcal Spendıng across the table's three panels, where political 
spending is variously represented by changes in PAC contributions, in lobbying expenditures, and in the number of tax-related lobbying reports filed in the 2003-2004 congressional cycle. The marginal effects in Table $4 \mathrm{~B}$ can be interpreted as the amount of repatriation per dollar of assets associated with the cube root of the change in political spending. Thus, to compute the effect of an increase of $\$ 100,000$ in PAC contributions on repatriation, we multiply $\$ 100,000^{(1 / 3)}$ by the coefficient on political spending, i.e., 0.000827 , which yields an association of about $3.839 \%$ of assets. For the median firm in the regression with $\$ 5.094$ billion in assets, this translates into about $\$ 195.54$ million repatriated.

Under the provisions of the Act, $85 \%$ of that amount is exempt from taxation. The taxes owed on the remaining $15 \%$ are approximately the difference between the U.S. tax rate (a maximum of 35\% during the repatriation period) and the firm's average foreign tax rate (foreign taxes paid are a credit in computing U.S. tax liability). For the median firm in the sample, the average foreign tax rate is about $25.59 \%$. Assuming the median firm is at the 35\% U.S. tax bracket, the $\$ 195.54$ million repatriated in association with $\$ 100,000$ of increased PAC spending results in a tax liability under the Act of about $\$ 2.76$ million and thus, about $\$ 15.64$ million in taxes saved. To see this, note that under the Act, taxes owed on the $\$ 195.54$ million are $=\$ 195.54$ million $* 15 \% *(35 \%-$ $25.59 \%)=\$ 2.76$ million. Without the Act, taxes owed on $\$ 195.54$ million would be $=$ $\$ 195.54$ million $*(35 \%-25.59 \%)=\$ 18.4$ million. Thus, tax savings under the Act are $=$ $\$ 18.4$ million $-\$ 2.76$ million $=\$ 15.64$ million.

As noted earlier, in computing political returns it can be more informative to use the levels of political spending because levels represent the total political investment in a 
given period. The marginal effects in Table 5B, which represent the amount of repatriation per dollar of assets associated with the cube root of the level in political spending, can be used to generate such return estimates. To compute the effect of $\$ 100,000$ level of PAC contributions on repatriation, we multiply $\$ 100,000^{(1 / 3)}$ by the coefficient on lobbying spending from Table 5B, i.e., 0.000451 , which yields an association of about $2.094 \%$ of assets. For the median firm in the regression with $\$ 5.094$ billion in assets, this translates into about $\$ 106.65$ million repatriated. Using a calculation similar to that in the preceding paragraph, we can estimate that the $\$ 106.65$ million repatriated in association with $\$ 100,000$ million of PAC spending results in a tax liability under the Act of about $\$ 1.5$ million and thus, about $\$ 8.53$ million in taxes saved.

Table 6 provides estimates of taxes saved on repatriations that are associated with changes in and levels of political spending, as predicted by the coefficients on Politıcal Spending in Tables 4B and 5B. There are three columns in Table 6, corresponding to estimates of tax savings associated with $\$ 100,000$ in PAC contributions, $\$ 1$ million in lobbying expenditures, and the filing of ten tax-related lobbying reports. ${ }^{8}$ In Panel A of Table 6, we use the coefficients from the regressions using changes in political spending (Table 4B). In Panel B of Table 6, we use the coefficients from the regressions using levels in political spending (Table 5B). In both panels, we assume the average foreign tax rate is at the sample median, i.e., 25.59\%. From Panel A we learn that for the median firm in sample with $\$ 5.09$ billion in assets, $\$ 1$ million increase in lobbying expenditures (over the firm's prior cycle spending) results in about $\$ 32.35$ million in

\footnotetext{
${ }^{8}$ We choose $\$ 100,000$ as the illustrative for computing returns to PAC contributions, since PAC contributions are limited in magnitude by law.
} 
taxes saved. And, from Panel B we learn that for the median firm in sample with $\$ 5.09$ billion in assets, \$1 million level of lobbying expenditures results in about $\$ 7.21$ million in taxes saved.

A similar calculation for changes in the number of tax-related lobbying reports (Panel A) suggests that the filing of ten additional reports is associated with about $\$ 21.08$ million in taxes saved; while the calculation for levels in tax-related lobbying reports (Panel B) suggests that ten such reports are associated with about $\$ 9.89$ million in taxes saved. Table 6 also provides estimates for the returns to changes and levels in political spending for the $25^{\text {th }}$ and $75^{\text {th }}$ percentile size firms in the sample, with $\$ 1.817$ billion $\$ 17.038$ billion in assets, respectively.

In un-tabulated calculations, we assume the average foreign tax rate is at the $25^{\text {th }}$ percentile of the sample, i.e., $11.38 \%$. With a lower foreign tax rate, firms can expect to pay more in U.S. taxes; thus, repatriation under the Act becomes more valuable. For the median size firm in sample with $\$ 5.094$ billion in assets, $\$ 1$ million $(\$ 100,000)$ level of lobbying expenditures (PAC contributions) results in about $\$ 18.10(\$ 21.41)$ million in taxes saved. A similar calculation for the number of tax-related lobbying reports suggests that the filing of ten tax reports is associated with about $\$ 24.82$ million in taxes saved. ${ }^{9}$

\subsection{Sensitivity tests}

In additional tests, we repeat the regressions in Tables $4 \mathrm{~B}$ and $5 \mathrm{~B}$ using the observed values of the changes in and levels of corporate political spending in lieu of

\footnotetext{
${ }^{9}$ We do not provide estimates of taxes saved on repatriations when the firm is at the $75^{\text {th }}$ percentile of average foreign tax rate. The reason is that average foreign tax rate at the $75^{\text {th }}$ percentile of the sample is over $38 \%$, which exceeds the maximum U.S. tax rate in that period. Thus, sample firms in the $75^{\text {th }}$ percentile of average foreign tax rate do not receive any benefit from repatriating under the Act.
} 
Polıtıcal Spendıng. In other words, we repeat the regressions without addressing the potential omitted-variable bias induced by our reliance on the Blouin and Krull model of economic determinants of repatriation. The coefficients on the proxies for corporate political spending in these regressions remain positive and statistically significant; however, they are about twice in magnitude of those reported in Tables 4B and 5B. For example, for the median size firm in sample with $\$ 5.094$ billion in assets and assuming the average foreign tax rate is at the sample median, i.e., $25.59 \%, \$ 1$ million $(\$ 100,000)$ level of lobbying expenditures (PAC contribution) results in about \$21.6 (\$25.6) million in taxes saved. A similar calculation for the number of tax-related lobbying reports suggests that the filing of ten such reports is associated with about \$29.67 million in taxes saved.

These higher return estimates suggest that not instrumenting for corporate political spending can result in overstating the return on corporate political contributions. This finding is particularly significant given the wide coverage received by the Alexander et al. (2009) study. That study does not address the key methodological concerns associated with estimating returns to political spending.

\section{Conclusion}

We examine the returns to corporate political spending on what became the American Jobs Creation Act of 2004. Our setting and research methods partly overcome two challenges prior literature encounters when estimating political returns: quantifying the benefit from a given legislation or regulation; and isolating the investment in political spending to achieve that benefit (since firms can engage in political spending for many reasons). We find that repatriation under the Act is an increasing function of prior 
political spending, after instrumenting for that spending. The instrument for political spending in our model is the ideology of the congressperson historically receiving the most contributions from the firm in question. We use the historical level of contributions between firm and congressperson to proxy for the relationship between the two (e.g., Snyder, 1992), so the congressperson with the most contributions is assumed to have a strong relationship with the firm. That congressperson's ideology is used to instrument for the firm's tax-related political spending: the expectation being the more conservative the firm's allies in Congress, the less the tax-related political spending (since conservative congresspersons are more likely to support lower taxes).

Our tests allow us to estimate the economic return to corporate political spending on the repatriation-tax holiday in the Act. Specifically, we find for the median politically active firm in our sample that an increase in $\$ 1$ million in lobbying expenditures is associated with about $\$ 32.35$ million in taxes saved, an increase in $\$ 100,000$ of PAC contributions is associated with about $\$ 15.64$ million in taxes saved, and that the additional filing of ten tax-related lobbying reports is associated with about $\$ 21.08$ million in taxes saved. Our estimates differ sharply from those generated in prior academic analyses (Alexander et al., 2009) and subsequently circulated in the press (e.g., Eggen, 2009; Newman, 2011). In particular, Alexander et al. suggest that firms lobbying for the American Jobs Creation Act "have a return in excess of $\$ 220$ for every $\$ 1$ spent on lobbying."

Our results are relevant in light of recent attempts to generate support in the Congress for another "one-time" tax break on repatriated foreign income (e.g., Worstall, 2013; Stephenson and Temple-West, 2014). Moreover, our setting allows us to offer 
relatively precise estimates of returns to lobbying. Although the link between corporate tax-related benefits and special-interest lobbying has been widely theorized (e.g., Stigler, 1971; Dixit, Grossman, and Helpman, 1997; Hanlon and Heitzman, 2010), there is little formal evidence on the causal relation between the two. Our estimates, generated through the use of a novel instrumental variable, offer some indication of the magnitudes of corporate political returns in the United States.

A final few notes on interpreting our results: First, we focus on political investments for a repatriation-tax holiday during a single congressional cycle and do not consider political investments on this issue that firms may have made in prior cycles. To the extent that these prior investments also contributed to the repatriation-tax holiday's passage in 2004, our return estimates could be biased upwards. Therefore, our returns should be interpreted as the upper-bound estimates of the "true" return value. Second, the relation between political spending and lower taxation does not necessarily imply that politicians involved in the process were bribed. The alternative hypothesis to explain the role of money in politics is that politicians are "busy" individuals with numerous competing interests on their time. Political spending plays a crucial role in that it enables special-interest groups to attract politicians to their causes, since money represents a credible signal of the importance of a cause. In the context of this hypothesis, the role of political spending in the American Jobs Creation Act can be viewed as efficiency enhancing. 


\section{References}

Alexander, R., S. Scholz, and S. Mazza. 2009. Measuring rates of return on lobbying expenditures: An empirical case study of tax breaks for multinational corporations. Journal of Law and Politics 25: 401.

Ansolabehere, S., J. de Figueiredo, and J. Snyder, Jr. 2003. Why is there so little money in U.S. Politics? Journal of Economic Perspectives 17 (1): 105-130.

Ansolabehere, S., J. Snyder, Jr., and M. Tripathi. 2002. Are PAC contributions and lobbying linked? New evidence from the 1995 Lobby Disclosure Act. Business and Politics 4 (2): 131-155.

Birnbaum, J. 2006. Clients' rewards keep K Street lobbyists thriving. Washington Post, Feb. 14.

Blouin, J., and L. Krull. 2009. Bringing It Home: A Study of the Incentives Surrounding the Repatriation of Foreign Earnings Under the American Jobs Creation Act of 2004. Journal of Accounting Research 47 (4): 1027-1059.

Cooper, M., H. Gulen, and A. Ovtchinnikov. 2010. Corporate political contributions and stock returns. Journal of Finance 65 (2): 687-724.

Dharmapala, D., C. Foley, and K. Forbes. 2011. Watch What I Do, Not What I Say: The Unintended Consequences of the Homeland Investment Act. Journal of Finance 66 (3): 753-787.

Dixit, A., G. Grossman, and E. Helpman. 1997. Common agency and coordination: General theory and application to tax policy. Journal of Political Economy 105 (4): 752769.

Eggen, D. 2009. Investments can yield more on K Street, study indicates. Washington Post, April 12.

Eggen, D. 2011. The Influence Industry: Companies lobbying for a tax holiday on overseas money. Washington Post, April 27.

Faulkender, M., and M. Petersen. 2012. Investment and capital constraints: repatriations under the American Jobs Creation Act. Review of Financial Studies 25 (11): 3351-3388.

Graham, J., H. Hanlon and T. Shevlin. 2010. Barriers to mobility: The lockout effect of U.S. taxation of worldwide corporate profits. National Tax Journal 63 (4): 1111-1144.

Hanlon, M., and S. Heitzman. 2010. A review of tax research. Journal of Accounting and Economics 50 (2): 127-178. 
Hillman, A., Keim, G., and D. Schuler. 2004. Corporate Political Activity: A Review and Research Agenda. Journal of Management 30 (6): 837-857.

Hook, J., and D. Yadron. 2013. Apple CEO Tim Cook, Lawmakers Square Off Over Taxes. Wall Street Journal, May 21.

Jayachandran, S. 2006. The Jeffords Effect. Journal of Law and Economics 49 (2): $397-$ 425.

Lessig, L. 2011. Republic, Lost: How Money Corrupts Congress--and a Plan to Stop It. Hachette Digital, Inc.

McKinnon, J. 2009. Multinationals push to revive tax break. The Wall Street Journal, February 3.

Murphy, M. 2014. Top Congressmen Support Repatriation Vacation. The Wall Street Journal, June 11.

Newman, D. 2011. How These Companies Earned a 22,000\% Return. The Motley Fool, December 27.

O'Brien, M. 2014. The Trillions of Dollars U.S. Companies Are Hoarding Overseas. The Atlantic, March.

Oler, M., T. Shevlin, and R. Wilson. 2007. Examining investor expectations concerning tax savings on the repatriation of foreign earnings under the American Jobs Creation Act of 2004, Journal of the American Taxation Association 29 (2): 25-55.

Poole, K. 1998. Recovering a Basic Space From a Set of Issue Scales. American Journal of Political Science 42 (August): 954-993.

Pozen, R. 2014. A Better Path to Corporate Tax Reform. The Wall Street Journal, February 18.

Roberts, B. 1990. A dead senator tells no lies: Seniority and the distribution of federal benefits. American Journal of Political Science 34 (1): 31-58.

Rubin, R. 2012. Cisco-backed Repatriation Tax-Break Lobby Effort Ceases. Bloomberg, April 24.

Snyder Jr., J. 1992. Long-term investing in politicians; or, give early, give often. Journal of Law and Economics 35 (1): 15-43.

Stephenson, E., and P. Temple-West. 2014. Senators weigh tax 'holiday' to help fund highway repairs. Reuters, June 10.

Stigler, G. 1971. The theory of economic regulation. Bell Journal of Economics 2 (1): 359-365. 
Stock, J., Wright J., and M. Yogo. 2002. A survey of weak instruments and weak identification in generalized method of moments. Journal of Business and Economics Statistics 20 (4): 518-529.

Stratmann, T. 2005. Some Talk: Money in Politics. A (Partial) Review of the Literature. Public Choice 124 (1): 135-156.

Tullock, G. 1972. The Purchase of Politicians. Western Economic Journal. 10: 354-55.

Waters, R. 2014. Corporate America's overseas cash pile rises to \$947bn. Financial Times, March 31.

Worstall, R. 2013. Apple's Tim Cook to Propose Profit Repatriation Tax Changes. Forbes, May 18.

U.S. House. 2004. Providing for consideration of the bill (H.R. 4520) to amend the Internal Revenue Code of 1986 to remove impediments in such Code and make our manufacturing, service, and high-technology businesses and workers more competitive and productive both at home and abroad. House Resolution $681,108^{\text {th }}$ Congress, $2^{\text {nd }}$ Session. 


\section{Appendix A \\ Excerpt of the report for the second-half of 2004 filed by Williams \& Jensen, PC, on lobbying for Dell Computer Corporation}
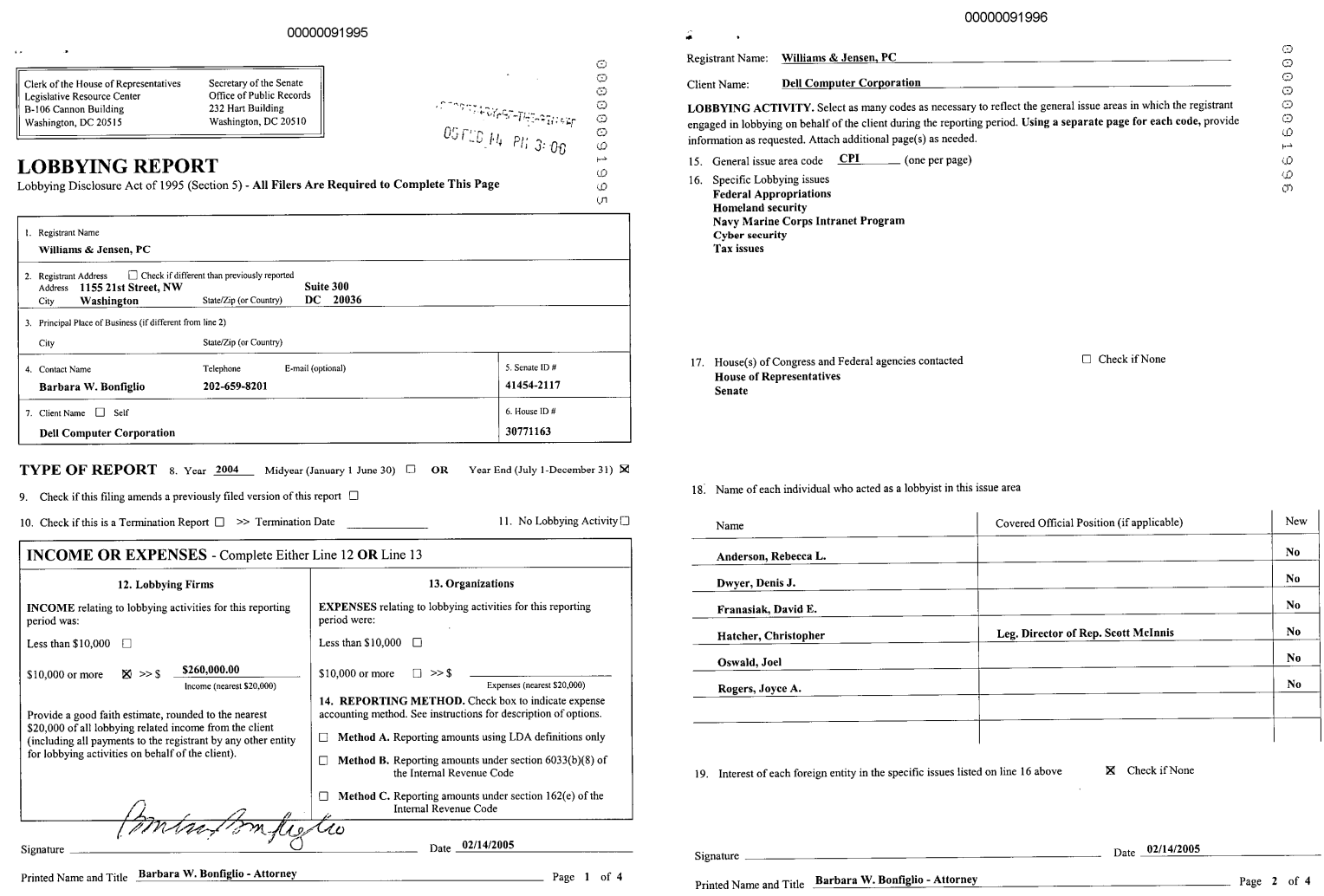

Source: Senate Office of Public Records 


\section{Appendix B \\ Summary of tax bills receiving House floor action in the $108^{\text {th }}$ Congress}

Panel A: Breakdown by last-achieved stage in the legislative process

\begin{tabular}{ll}
\hline Last major action & Number of bills \\
\hline Floor action in the House & 41 \\
Passed by the House & 41 \\
Floor action in the Senate & 21 \\
Passed by the Senate & 20 \\
Cleared for the White House & 16 \\
Signed into Law & 16 \\
\hline
\end{tabular}

Panel B: Breakdown by bills' major focus

\begin{tabular}{ll}
\hline Major focus of the bill & Number of bills \\
\hline Personal taxes & 20 \\
Corporate income tax (the AJCA) & 1 \\
Tax code reform/simplification & 4 \\
Tariff/duty & 2 \\
Pension/retirement plan & 3 \\
Energy & 1 \\
Transportation & 5 \\
Healthcare/Medicare & 2 \\
Others* & 3 \\
Total & 41 \\
\hline * These three tax bills concern issues related to the YMCA retirement fund, archery products importation, \\
and arrow component production.
\end{tabular}


Table 1

Summary statistics for changes and levels in political spending

\begin{tabular}{|c|c|c|c|c|c|}
\hline & \multirow{2}{*}{\multicolumn{2}{|c|}{$\begin{array}{c}\text { Sample firms: } \\
\text { politically active U.S. } \\
\text { firms with overseas } \\
\text { operations } \\
\mathrm{n}=513\end{array}$}} & \multirow{2}{*}{\multicolumn{2}{|c|}{$\begin{array}{l}\text { Politically active U.S. } \\
\text { firms without overseas } \\
\text { operations } \\
n=367\end{array}$}} & \\
\hline & & & & & \\
\hline & Mean & Median & Mean & Median & \\
\hline$\triangle \mathrm{PAC}$ & $\$ 21,401$ & $\$ 4,000$ & $\$ 13,993$ & $\$ 500$ & \\
\hline$\Delta$ Lobbying & $\$ 292,753$ & $\$ 0$ & $\$ 72,899$ & $\$ 0$ & $* *$ \\
\hline$\Delta$ Tax Reports & 0.66 & 0.00 & 0.15 & 0.00 & $* *$ \\
\hline PAC contributions & $\$ 118,569$ & $\$ 38,999$ & $\$ 62,592$ & $\$ 15,000$ & $* * *$ \\
\hline Lobbying expenditures & $\$ 1,360,077$ & $\$ 0$ & $\$ 323,171$ & $\$ 0$ & $* * *$ \\
\hline Tax-related lobbying reports & 2.97 & 0.00 & 1.05 & 0.00 & $* * *$ \\
\hline
\end{tabular}

The sample of 513 firms is the primary sample - politically active U.S. firms with overseas operations during our period of interest (that is, at least since 1998 and at least through 2006). The sample of 367 firms includes politically active U.S. firms without overseas operations during our period of interest. $\triangle$ PAC is the change in PAC contributions from the $108^{\text {th }}$ to the $107^{\text {th }}$ Congress. $\Delta$ Lobbying is the change in lobbying expenditures from the $108^{\text {th }}$ to the $107^{\text {th }}$ Congress. $\Delta$ Tax Reports is the change in the number of tax-related lobbying reports from the $108^{\text {th }}$ to the $107^{\text {th }}$ Congress. The levels of political spending, reported in the last three rows, are for the $108^{\text {th }}$ Congress. The notations $* *$ and $* * *$ signify that the difference in means in a given row is statistically significant at the $95 \%$ and $99 \%$ confidence levels, respectively. 
Table 2

Pearson correlations between proxies for changes and levels in political spending

\begin{tabular}{llllll}
\hline & $\Delta$ PAC & $\Delta$ Lobbying & $\begin{array}{l}\Delta \text { Tax } \\
\text { Reports }\end{array}$ & $\begin{array}{l}\text { PAC } \\
\text { contributions }\end{array}$ & $\begin{array}{l}\text { Lobbying } \\
\text { expenditures }\end{array}$ \\
\hline$\Delta$ Lobbying & $0.21^{* * *}$ & & & \\
$\Delta$ Tax Reports & $0.08^{*}$ & $0.23^{* * *}$ & & \\
PAC contributions & $0.39^{* * *}$ & $0.30^{* * *}$ & $0.19^{* * *}$ & & \\
Lobbying expenditures & $0.21^{* * *}$ & $0.55^{* * *}$ & $0.23^{* * *}$ & $0.61^{* * *}$ & \\
Tax-related lobbying reports & $0.14^{* * *}$ & $0.33^{* * *}$ & $0.47^{* * *}$ & $0.62^{* * *}$ & $0.70^{* * *}$ \\
\hline
\end{tabular}

The sample is politically active U.S. firms with overseas operations during our period of interest (that is, at least since 1998 and at least through 2006). $\triangle$ PAC is the change in PAC contributions from the $108^{\text {th }}$ to the $107^{\text {th }}$ Congress. $\Delta$ Lobbying is the change in lobbying expenditures from the $108^{\text {th }}$ to the $107^{\text {th }}$ Congress. $\Delta$ Tax Reports is the change in the number of tax-related lobbying reports from the $108^{\text {th }}$ to the $107^{\text {th }}$ Congress. The levels of political spending - denoted PAC contributions, Lobbying expenditures, and Tax-related lobbying reports - are for the $108^{\text {th }}$ Congress. All political spending variables are subject to a cube-root transformation and are winsorized at $1 \%$ and $99 \%$ values. The notations * and $* * *$ represent statistically significance at the $90 \%$ and $99 \%$ confidence levels, respectively. 


\section{Table 3}

\section{Summary statistics for variables other than those measuring political spending}

\begin{tabular}{|c|c|c|}
\hline Variable & Mean & Median \\
\hline Repatriation & 0.021 & 0.000 \\
\hline AllyIdeology & 0.150 & 0.236 \\
\hline$\triangle R O A$ & -0.006 & 0.000 \\
\hline$\triangle M B$ & -0.358 & 0.005 \\
\hline$\Delta R D$ & 0.000 & 0.000 \\
\hline$\triangle$ CapEx & -0.005 & -0.002 \\
\hline$F C F$ & 0.091 & 0.082 \\
\hline USTR & 0.070 & 0.000 \\
\hline$\triangle F P T I$ & 0.001 & 0.000 \\
\hline RateDum & 0.881 & 1.000 \\
\hline$\%$ FAssets & 0.193 & 0.079 \\
\hline
\end{tabular}

The sample is politically active U.S. firms with overseas operations during our period of interest (that is, at least since 1998 and at least through 2006). Repatriation is the dollar amount of repatriation under the Act, scaled by firm assets. AllyIdeology is our instrument - it is the value of congressional ideology (first dimension of the Common Space Score) for the congressperson receiving the most contributions from the firm in question during the $107^{\text {th }}$ Congress (see Section 3 for more details). $\triangle R O A$ is the change in net income scaled by worldwide assets for the period 2001 to 2004. $\triangle M B$ is the change in the firm's market value to book value ratio for the period 2001 to 2004 . $\triangle R D$ is the change in the ratio of research and development expenses to worldwide assets for the period 2001 to 2004. $\triangle$ CapEx is the change in capital expenditures divided by worldwide assets for the period 2001 to 2004. FCF is the average operating cash flows divided by worldwide assets for the period 2001 to 2004. USTR is the average U.S. tax rate from 2001 through 2004. $\triangle F P T I$ is the change in foreign pre-tax income scaled by worldwide assets.

RateDum is a dummy variable set to one if the U.S. tax rate of $35 \%$ exceeds the average foreign tax rate from 2001 to 2004, zero otherwise. \%FAssets is the ratio of foreign assets (estimated as described in Oler et al., 2007) to worldwide assets. All continuous variables have been winsorized at the top and bottom $1 \%$ of the distribution. 
Table 4A

First stage of the 2SLS regression: OLS using changes in political spending

\begin{tabular}{|c|c|c|c|}
\hline & $\triangle \mathrm{PAC}$ & $\Delta$ Lobbying & $\Delta$ Tax Reports \\
\hline Constant & $\begin{array}{l}10.14 \\
(0.03)\end{array}$ & $\begin{array}{l}10.90 \\
(0.22)\end{array}$ & $\begin{array}{c}0.10 \\
(0.49)\end{array}$ \\
\hline AllyIdeology & $\begin{array}{c}-12.39 \\
(0.00)\end{array}$ & $\begin{array}{l}-12.90 \\
(0.07)\end{array}$ & $\begin{array}{c}-0.43 \\
(0.00)\end{array}$ \\
\hline$\triangle R O A$ & $\begin{array}{c}-0.602 \\
(0.80)\end{array}$ & $\begin{array}{l}-0.728 \\
(0.88)\end{array}$ & $\begin{array}{l}-0.011 \\
(0.88)\end{array}$ \\
\hline$\triangle M B$ & $\begin{array}{l}0.021 \\
(0.67)\end{array}$ & $\begin{array}{l}-0.002 \\
(0.98)\end{array}$ & $\begin{array}{l}0.000 \\
(0.92)\end{array}$ \\
\hline$\triangle R D$ & $\begin{array}{c}-191.27 \\
(0.35)\end{array}$ & $\begin{array}{c}-417.83 \\
(0.30)\end{array}$ & $\begin{array}{l}-8.56 \\
(0.17)\end{array}$ \\
\hline$\triangle C a p E x$ & $\begin{array}{l}79.39 \\
(0.38)\end{array}$ & $\begin{array}{c}-100.60 \\
(0.56)\end{array}$ & $\begin{array}{l}-3.93 \\
(0.15)\end{array}$ \\
\hline$F C F$ & $\begin{array}{l}22.87 \\
(0.17)\end{array}$ & $\begin{array}{c}9.06 \\
(0.78)\end{array}$ & $\begin{array}{c}1.22 \\
(0.02)\end{array}$ \\
\hline USTR & $\begin{array}{l}12.13 \\
(0.28)\end{array}$ & $\begin{array}{l}41.84 \\
(0.05)\end{array}$ & $\begin{array}{c}0.32 \\
(0.34)\end{array}$ \\
\hline$\triangle F P T I$ & $\begin{array}{c}233.44 \\
(0.30)\end{array}$ & $\begin{array}{c}293.48 \\
(0.50)\end{array}$ & $\begin{array}{c}3.82 \\
(0.58)\end{array}$ \\
\hline RateDum & $\begin{array}{l}-3.76 \\
(0.37)\end{array}$ & $\begin{array}{l}-5.98 \\
(0.46)\end{array}$ & $\begin{array}{l}-0.12 \\
(0.35)\end{array}$ \\
\hline$\%$ FAssets & $\begin{array}{l}-8.63 \\
(0.11)\end{array}$ & $\begin{array}{l}-3.30 \\
(0.75)\end{array}$ & $\begin{array}{c}0.21 \\
(0.21)\end{array}$ \\
\hline Weak Instrument Test (F-test) & 10.21 & 2.79 & 13.06 \\
\hline Adjusted $\mathrm{R}^{2}$ & 0.020 & 0.003 & 0.038 \\
\hline Number of observations & 511 & 511 & 511 \\
\hline
\end{tabular}

The sample is politically active U.S. firms with overseas operations during our period of interest (that is, at least since 1998 and at least through 2006). $\triangle$ PAC is the change in PAC contributions from the $108^{\text {th }}$ to the $107^{\text {th }}$ Congress. $\Delta$ Lobbying is the change in lobbying expenditures from the $108^{\text {th }}$ to the $107^{\text {th }}$ Congress. $\Delta$ Tax Reports is the change in the number of tax-related lobbying reports from the $108^{\text {th }}$ to the $107^{\text {th }}$ Congress. All political spending variables are subject to a cube-root transformation. AllyIdeology is our instrument - it is the value of congressional ideology (first dimension of the Common Space Score) for the congressperson receiving the most contributions from the firm in question during the $107^{\text {th }}$ Congress (see Section 3 for more details). $\triangle R O A$ is the change in net income scaled by worldwide assets for the period 2001 to 2004. $\triangle M B$ is the change in the firm's market value to book value ratio for the period 2001 to 2004. $\triangle R D$ is the change in the ratio of research and development expenses to worldwide assets for the period 2001 to 2004. $\triangle$ CapEx is the change in capital expenditures divided by worldwide assets for the period 2001 to 2004. FCF is the average operating cash flows divided by worldwide assets for the period 2001 to 2004. USTR is the average U.S. tax rate from 2001 through 2004. $\triangle F P T I$ is the change in foreign pre-tax income scaled by worldwide assets. RateDum is a dummy variable set to one if the U.S. tax rate of $35 \%$ exceeds the average 
foreign tax rate from 2001 to 2004, zero otherwise. \%FAssets is the ratio of foreign assets (estimated as described in Oler et al., 2007) to worldwide assets. All continuous variables have been winsorized at the top and bottom $1 \%$ of the distribution. Figures in parentheses are two-tailed p-values.

Table 4B

Second stage of the 2SLS regression: Tobit of Repatriation on predicted values of changes in political spending

\begin{tabular}{|c|c|c|c|c|}
\hline & \multirow{2}{*}{$\begin{array}{l}\text { Expected } \\
\text { sign }\end{array}$} & \multicolumn{3}{|c|}{ Repatriation } \\
\hline & & $\triangle \mathrm{PAC}$ & $\Delta$ Lobbying & $\Delta$ Tax Reports \\
\hline Constant & & $\begin{array}{c}-0.33 \\
(<.0001)\end{array}$ & $\begin{array}{c}-0.33 \\
(<.0001)\end{array}$ & $\begin{array}{c}-0.33 \\
(<.0001)\end{array}$ \\
\hline Polıtıcal Spendıng & + & $\begin{array}{c}0.000827 \\
(0.08)\end{array}$ & $\begin{array}{c}0.000794 \\
(0.08)\end{array}$ & $\begin{array}{c}0.024014 \\
(0.08)\end{array}$ \\
\hline$\triangle R O A$ & - & $\begin{array}{l}0.0022 \\
(0.83)\end{array}$ & $\begin{array}{l}0.0023 \\
(0.83)\end{array}$ & $\begin{array}{l}0.0020 \\
(0.83)\end{array}$ \\
\hline$\triangle M B$ & - & $\begin{array}{c}-0.0004 \\
(0.22)\end{array}$ & $\begin{array}{c}-0.0003 \\
(0.24)\end{array}$ & $\begin{array}{c}-0.0004 \\
(0.23)\end{array}$ \\
\hline$\triangle R D$ & - & $\begin{array}{c}-0.7760 \\
(0.00)\end{array}$ & $\begin{array}{c}-0.6024 \\
(0.00)\end{array}$ & $\begin{array}{c}-0.7288 \\
(0.00)\end{array}$ \\
\hline$\triangle C a p E x$ & - & $\begin{array}{c}-0.2433 \\
(0.33)\end{array}$ & $\begin{array}{c}-0.0977 \\
(0.43)\end{array}$ & $\begin{array}{c}-0.0833 \\
(0.42)\end{array}$ \\
\hline$F C F$ & + & $\begin{array}{l}0.0807 \\
(0.00)\end{array}$ & $\begin{array}{l}0.0924 \\
(0.00)\end{array}$ & $\begin{array}{l}0.0704 \\
(0.00)\end{array}$ \\
\hline USTR & + & $\begin{array}{c}0.0671 \\
(<.0001)\end{array}$ & $\begin{array}{c}0.0439 \\
(<.0001)\end{array}$ & $\begin{array}{c}0.0693 \\
(<.0001)\end{array}$ \\
\hline$\triangle F P T I$ & - & $\begin{array}{c}-0.3485 \\
(0.40)\end{array}$ & $\begin{array}{c}-0.3885 \\
(0.41)\end{array}$ & $\begin{array}{c}-0.2472 \\
(0.54)\end{array}$ \\
\hline RateDum & + & $\begin{array}{l}0.0165 \\
(0.01)\end{array}$ & $\begin{array}{l}0.0181 \\
(0.01)\end{array}$ & $\begin{array}{l}0.0163 \\
(0.01)\end{array}$ \\
\hline$\%$ FAssets & + & $\begin{array}{c}0.0631 \\
(<.0001)\end{array}$ & $\begin{array}{c}0.0586 \\
(<.0001)\end{array}$ & $\begin{array}{c}0.0510 \\
(<.0001)\end{array}$ \\
\hline Sigma & & $\begin{array}{c}0.1400 \\
(<.0001)\end{array}$ & $\begin{array}{c}0.1400 \\
(<.0001)\end{array}$ & $\begin{array}{c}0.1400 \\
(<.0001)\end{array}$ \\
\hline Log-likelihood & & -36.90 & -36.90 & -36.90 \\
\hline Number of observations & & 511 & 511 & 511 \\
\hline
\end{tabular}

The sample is politically active U.S. firms with overseas operations during our period of interest (that is, at least since 1998 and at least through 2006). Repatriation is the dollar amount of repatriation under the Act, scaled by firm assets. $\triangle$ PAC is the change in PAC contributions from the $108^{\text {th }}$ to the $107^{\text {th }}$ Congress. $\Delta$ Lobbying is the change in lobbying expenditures from the $108^{\text {th }}$ to the $107^{\text {th }}$ Congress. $\Delta$ Tax Reports is the change in the number of tax-related 
lobbying reports from the $108^{\text {th }}$ to the $107^{\text {th }}$ Congress. All political spending variables are subject to a cube-root transformation. $\triangle R O A$ is the change in net income scaled by worldwide assets for the period 2001 to $2004 . \triangle M B$ is the change in the firm's market value to book value ratio for the period 2001 to 2004 . $\triangle R D$ is the change in the ratio of research and development expenses to worldwide assets for the period 2001 to 2004. $\triangle$ CapEx is the change in capital expenditures divided by worldwide assets for the period 2001 to 2004. FCF is the average operating cash flows divided by worldwide assets for the period 2001 to 2004. USTR is the average U.S. tax rate from 2001 through 2004. $\triangle F P T I$ is the change in foreign pre-tax income scaled by worldwide assets. RateDum is a dummy variable set to one if the U.S. tax rate of $35 \%$ exceeds the average foreign tax rate from 2001 to 2004, zero otherwise. \%FAssets is the ratio of foreign assets (estimated as described in Oler et al., 2007) to worldwide assets. All continuous variables have been winsorized at the top and bottom $1 \%$ of the distribution. Except for the Constant and Sigma, the marginal effect of each variable on Repatriation is presented. Figures in parentheses are two-tailed p-values. 
Table 5A

First stage of the 2SLS regression: OLS using levels of political spending

\begin{tabular}{|c|c|c|c|}
\hline & $\begin{array}{c}\text { PAC } \\
\text { contributions }\end{array}$ & $\begin{array}{c}\text { Lobbying } \\
\text { expenditures }\end{array}$ & $\begin{array}{c}\text { Tax-related } \\
\text { lobbying } \\
\text { reports }\end{array}$ \\
\hline Constant & $\begin{array}{c}33.82 \\
(<.0001)\end{array}$ & $\begin{array}{c}51.88 \\
(<.0001)\end{array}$ & $\begin{array}{c}0.74 \\
(<.0001)\end{array}$ \\
\hline AllyIdeology & $\begin{array}{c}-22.72 \\
(<.0001)\end{array}$ & $\begin{array}{c}-57.75 \\
(<.0001)\end{array}$ & $\begin{array}{c}-0.91 \\
(<.0001)\end{array}$ \\
\hline$\triangle R O A$ & $\begin{array}{l}0.010 \\
(1.00)\end{array}$ & $\begin{array}{l}-0.276 \\
(0.96)\end{array}$ & $\begin{array}{l}0.000 \\
(1.00)\end{array}$ \\
\hline$\triangle M B$ & $\begin{array}{l}0.029 \\
(0.53)\end{array}$ & $\begin{array}{l}-0.015 \\
(0.90)\end{array}$ & $\begin{array}{l}0.000 \\
(0.81)\end{array}$ \\
\hline$\triangle R D$ & $\begin{array}{c}1.89 \\
(0.99)\end{array}$ & $\begin{array}{l}-47.23 \\
(0.92)\end{array}$ & $\begin{array}{l}-2.52 \\
(0.71)\end{array}$ \\
\hline$\triangle C a p E x$ & $\begin{array}{l}-41.20 \\
(0.63)\end{array}$ & $\begin{array}{c}-272.31 \\
(0.21)\end{array}$ & $\begin{array}{l}-3.93 \\
(0.19)\end{array}$ \\
\hline$F C F$ & $\begin{array}{l}11.81 \\
(0.46)\end{array}$ & $\begin{array}{l}-0.75 \\
(0.99)\end{array}$ & $\begin{array}{c}0.16 \\
(0.77)\end{array}$ \\
\hline USTR & $\begin{array}{l}-7.08 \\
(0.50)\end{array}$ & $\begin{array}{l}32.83 \\
(0.23)\end{array}$ & $\begin{array}{c}0.55 \\
(0.14)\end{array}$ \\
\hline$\triangle F P T I$ & $\begin{array}{c}225.50 \\
(0.29)\end{array}$ & $\begin{array}{l}543.95 \\
(0.32)\end{array}$ & $\begin{array}{c}2.60 \\
(0.73)\end{array}$ \\
\hline RateDum & $\begin{array}{l}-5.21 \\
(0.19)\end{array}$ & $\begin{array}{l}-17.14 \\
(0.08)\end{array}$ & $\begin{array}{l}-0.26 \\
(0.07)\end{array}$ \\
\hline$\%$ FAssets & $\begin{array}{l}-17.38 \\
(0.00)\end{array}$ & $\begin{array}{l}-11.74 \\
(0.37)\end{array}$ & $\begin{array}{c}0.06 \\
(0.73)\end{array}$ \\
\hline Weak Instrument Test (F-test) & 39.19 & 39.59 & 52.23 \\
\hline Adjusted $\mathrm{R}^{2}$ & 0.079 & 0.072 & 0.097 \\
\hline Number of observations & 511 & 511 & 511 \\
\hline
\end{tabular}

The sample is politically active U.S. firms with overseas operations during our period of interest (that is, at least since 1998 and at least through 2006). The levels of political spending - denoted PAC contributions, Lobbying expenditures, and Tax-related lobbying reports - are for the $108^{\text {th }}$ Congress. All political spending variables are subject to a cube-root transformation. AllyIdeology is our instrument - it is the value of congressional ideology (first dimension of the Common Space Score) for the congressperson receiving the most contributions from the firm in question during the $107^{\text {th }}$ Congress (see Section 3 for more details). $\triangle R O A$ is the change in net income scaled by worldwide assets for the period 2001 to 2004. $\triangle M B$ is the change in the firm's market value to book value ratio for the period 2001 to 2004. $\triangle R D$ is the change in the ratio of research and development expenses to worldwide assets for the period 2001 to 2004. $\triangle$ CapEx is the change in capital expenditures divided by worldwide assets for the period 2001 to 2004. FCF is the average operating cash flows divided by worldwide assets for the period 2001 to 2004. USTR is the average U.S. tax rate from 2001 through 2004. $\triangle F P T I$ is the change in foreign pre-tax income scaled by worldwide assets. RateDum is a dummy variable set to one if the U.S. tax rate of $35 \%$ exceeds the average foreign tax rate from 2001 to 2004, zero otherwise. \%FAssets is the ratio of foreign assets (estimated as described in 
Oler et al., 2007) to worldwide assets. All continuous variables have been winsorized at the top and bottom $1 \%$ of the distribution. Figures in parentheses are two-tailed p-values.

\section{Table 5B}

Second stage of the 2SLS regression: Tobit of Repatriation on predicted values of levels of political spending

\begin{tabular}{|c|c|c|c|c|}
\hline & \multirow{2}{*}{$\begin{array}{l}\text { Expected } \\
\text { sign }\end{array}$} & \multicolumn{3}{|c|}{ Repatriation } \\
\hline & & $\begin{array}{c}\text { PAC } \\
\text { contributions }\end{array}$ & $\begin{array}{c}\text { Lobbying } \\
\text { expenditures }\end{array}$ & $\begin{array}{c}\text { Tax-related } \\
\text { lobbying reports }\end{array}$ \\
\hline Constant & & $\begin{array}{c}-0.36 \\
(<.0001)\end{array}$ & $\begin{array}{c}-0.33 \\
(<.0001)\end{array}$ & $\begin{array}{c}-0.33 \\
(<.0001)\end{array}$ \\
\hline Politıcalspending & + & $\begin{array}{c}0.000451 \\
(0.08)\end{array}$ & $\begin{array}{c}0.000177 \\
(\mathbf{0 . 0 8})\end{array}$ & $\begin{array}{c}0.011266 \\
(0.08)\end{array}$ \\
\hline$\triangle R O A$ & - & $\begin{array}{l}0.0017 \\
(0.83)\end{array}$ & $\begin{array}{l}0.0018 \\
(0.83)\end{array}$ & $\begin{array}{l}0.0018 \\
(0.83)\end{array}$ \\
\hline$\triangle M B$ & - & $\begin{array}{c}-0.0004 \\
(0.22)\end{array}$ & $\begin{array}{c}-0.0003 \\
(0.24)\end{array}$ & $\begin{array}{c}-0.0004 \\
(0.23)\end{array}$ \\
\hline$\triangle R D$ & - & $\begin{array}{c}-0.9356 \\
(0.00)\end{array}$ & $\begin{array}{c}-0.9258 \\
(0.00)\end{array}$ & $\begin{array}{c}-0.9006 \\
(0.00)\end{array}$ \\
\hline$\triangle C a p E x$ & - & $\begin{array}{c}-0.1592 \\
(0.33)\end{array}$ & $\begin{array}{c}-0.1293 \\
(0.43)\end{array}$ & $\begin{array}{c}-0.1333 \\
(0.42)\end{array}$ \\
\hline$F C F$ & + & $\begin{array}{l}0.0943 \\
(0.00)\end{array}$ & $\begin{array}{l}0.0997 \\
(0.00)\end{array}$ & $\begin{array}{l}0.0978 \\
(0.00)\end{array}$ \\
\hline USTR & + & $\begin{array}{c}0.0803 \\
(<.0001)\end{array}$ & $\begin{array}{c}0.0713 \\
(<.0001)\end{array}$ & $\begin{array}{c}0.0709 \\
(<.0001)\end{array}$ \\
\hline$\triangle F P T I$ & - & $\begin{array}{c}-0.2573 \\
(0.40)\end{array}$ & $\begin{array}{c}-0.2519 \\
(0.41)\end{array}$ & $\begin{array}{c}-0.1847 \\
(0.54)\end{array}$ \\
\hline RateDum & + & $\begin{array}{c}0.0157 \\
(0.01)\end{array}$ & $\begin{array}{c}0.0166 \\
(0.01)\end{array}$ & $\begin{array}{c}0.0162 \\
(0.01)\end{array}$ \\
\hline$\%$ FAssets & + & $\begin{array}{c}0.0638 \\
(<.0001)\end{array}$ & $\begin{array}{c}0.0581 \\
(<.0001)\end{array}$ & $\begin{array}{c}0.0553 \\
(<.0001)\end{array}$ \\
\hline Sigma & & $\begin{array}{c}0.1400 \\
(<.0001)\end{array}$ & $\begin{array}{c}0.1400 \\
(<.0001)\end{array}$ & $\begin{array}{c}0.1400 \\
(<.0001)\end{array}$ \\
\hline Log-likelihood & & -36.90 & -36.90 & -36.90 \\
\hline Number of observations & & 511 & 511 & 511 \\
\hline
\end{tabular}

The sample is politically active U.S. firms with overseas operations during our period of interest (that is, at least since 1998 and at least through 2006). Repatriation is the dollar amount of repatriation under the Act, scaled by firm assets. The levels of political spending - denoted PAC contributions, Lobbying expenditures, and Tax-related lobbying reports - are for the $108^{\text {th }}$ Congress. All political spending variables are subject to a cube-root transformation. $\triangle R O A$ is the change in net income scaled by worldwide assets for the period 2001 to $2004 . \triangle M B$ is 
the change in the firm's market value to book value ratio for the period 2001 to $2004 . \triangle R D$ is the change in the ratio of research and development expenses to worldwide assets for the period 2001 to 2004. $\triangle$ CapEx is the change in capital expenditures divided by worldwide assets for the period 2001 to 2004. FCF is the average operating cash flows divided by worldwide assets for the period 2001 to 2004. USTR is the average U.S. tax rate from 2001 through 2004. $\triangle F P T I$ is the change in foreign pre-tax income scaled by worldwide assets. RateDum is a dummy variable set to one if the U.S. tax rate of 35\% exceeds the average foreign tax rate from 2001 to 2004, zero otherwise. \%FAssets is the ratio of foreign assets (estimated as described in Oler et al., 2007) to worldwide assets. All continuous variables have been winsorized at the top and bottom 1\% of the distribution. Except for the Constant and Sigma, the marginal effect of each variable on Repatriation is presented. Figures in parentheses are two-tailed p-values. 


\section{Table 6 \\ Return on political investment}

Panel A: Using coefficients from regressions on changes in political spending

\begin{tabular}{|c|c|c|c|}
\hline Firm asset size & $\begin{array}{l}\triangle \mathrm{PAC}= \\
\$ 100,000\end{array}$ & $\begin{array}{c}\Delta \text { Lobbying }= \\
\$ 1,000,000\end{array}$ & $\begin{array}{c}\Delta \text { Tax Reports } \\
=10\end{array}$ \\
\hline 25th percentile, $\$ 1.817$ billion & $\$ 5,578,734$ & $\$ 11,539,420$ & $\$ 7,519,021$ \\
\hline 50th percentile, $\$ 5.094$ billion & $\$ 15,640,105$ & $\$ 32,351,021$ & $\$ 21,079,744$ \\
\hline 75th percentile, $\$ 17.038$ billion & $\$ 52,311,761$ & $\$ 108,205,084$ & $\$ 70,505,826$ \\
\hline
\end{tabular}

Panel B: Using coefficients from regressions on levels of political spending

\begin{tabular}{|c|c|c|c|}
\hline Firm asset size & $\begin{array}{c}\text { PAC } \\
\text { contributions }= \\
\$ 100,000\end{array}$ & $\begin{array}{c}\text { Lobbying } \\
\text { expenditures }= \\
\$ 1,000,000\end{array}$ & $\begin{array}{l}\text { Tax-related } \\
\text { lobbying } \\
\text { reports }=10\end{array}$ \\
\hline 25th percentile, $\$ 1.817$ billion & $\$ 3,042,751$ & $\$ 2,572,390$ & $\$ 3,527,465$ \\
\hline 50th percentile, $\$ 5.094$ billion & $\$ 8,530,420$ & $\$ 7,211,752$ & $\$ 9,889,326$ \\
\hline 75th percentile, $\$ 17.038$ billion & $\$ 28,531,859$ & $\$ 24,121,284$ & $\$ 33,077,021$ \\
\hline
\end{tabular}

The sample is politically active U.S. firms with overseas operations during our period of interest (that is, at least since 1998 and at least through 2006). $\triangle$ PAC is the change in PAC contributions from the $108^{\text {th }}$ to the $107^{\text {th }}$ Congress. $\Delta$ Lobbying is the change in lobbying expenditures from the $108^{\text {th }}$ to the $107^{\text {th }}$ Congress. $\Delta$ Tax Reports is the change in the number of tax-related lobbying reports from the $108^{\text {th }}$ to the $107^{\text {th }}$ Congress. The levels of political spending - denoted PAC contributions, Lobbying expenditures, and Tax-related lobbying reports - are for the $108^{\text {th }}$ Congress. Calculations in the table assume that the average foreign tax rate is at the sample median, which is $25.59 \%$. 